\title{
Use Of Clinical Visitations As A Medium To Develop Critical Thinking Skills In Health Science Students
}

Genevieve Pinto Zipp, PT, Ed.D., Seton Hall University, USA Catherine Maher, PT, DPT, Seton Hall University, USA

\begin{abstract}
The results of this study suggests that students have positive perceptions regarding Class Supported Clinical Visitation (CSCV) as a learning technique that may promote active learning and critical thinking. While the data obtained from this limited educational experience cannot be generalized, it does offer some insight into the usefulness of the CSCV learning technique. Based upon these findings further work can begin to explore student's perceptions of its usefulness in a larger diverse health science student population. Second, future work must assess if CSCV is truly effective in developing a student's ability to think critically. Finally, one must ask is CSCV more effective than other active learning strategies currently used to promote critical thinking.
\end{abstract}

Keywords: critical thinking; clinical visitation; course organization

\section{INTRODUCTION}

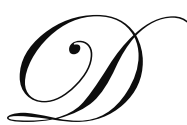

eveloping critical clinical thinking skills in health science students during their didactic coursework is a challenging goal for educators. In order to attempt to promote critical thinking educators must have a clear understanding of what critical thinking is. Bodner (1986) suggests that critical thinking is a form of purposeful judgment. Willingham (2007) suggests that critical thinking involves the identification of a problem, determination of how a problem can best be solved and the integration of content knowledge into the analysis of the problem. Koo \& Thacker (2008) suggests that critical thinking occurs via the process of reflection, deductive reasoning, inductive reasoning and finally analysis. A common thread in each of these definitions of critical thinking is the need to analyze information. Since health science students are adult learners who must analyze information on-going, one can offer the constructivists (assimilation) theory as a conceptual framework for adult learning. The constructivist's theory suggests that in order for meaningful learning (learning with understanding) to occur, learners must link new information with existing information. (Figure 1) Details the theoretical assumptions that underlie constructivist theory using a bottom-up approach (adapted from Ausubel, 1978).

As educators it is our goal to develop the students' clinical thought processes-that is to say, to create critical thinkers. When trying to develop critical thinking in students what is the best way to organizing the learning environment. Is there one preferred teaching and learning strategy to promote critical thinking in health sciences students? As demonstrated in Figure 2, the promotion of critical thinking can be achieved through the integration of both the enhancement of knowledge from the academy (basic sciences and clinical experiences) and learning opportunities which emerges from the issues impacting today's community.

So how does a health science educator ensure that the integration between the knowledge gained from the academy is routed in real world issues facing the community and thus promoting the students development as a critical thinker? Physical therapy educators have utilized numerous learning strategies including journals, practice patterns, problem-based learning, case studies, and hypothesis-oriented algorithm for clinicians (HOAC) (Shepard et al., 2002) to help students to develop their abilities to think critically during didactic coursework. Although educators use these strategies, their effectiveness in promoting critical thinking is not known. 


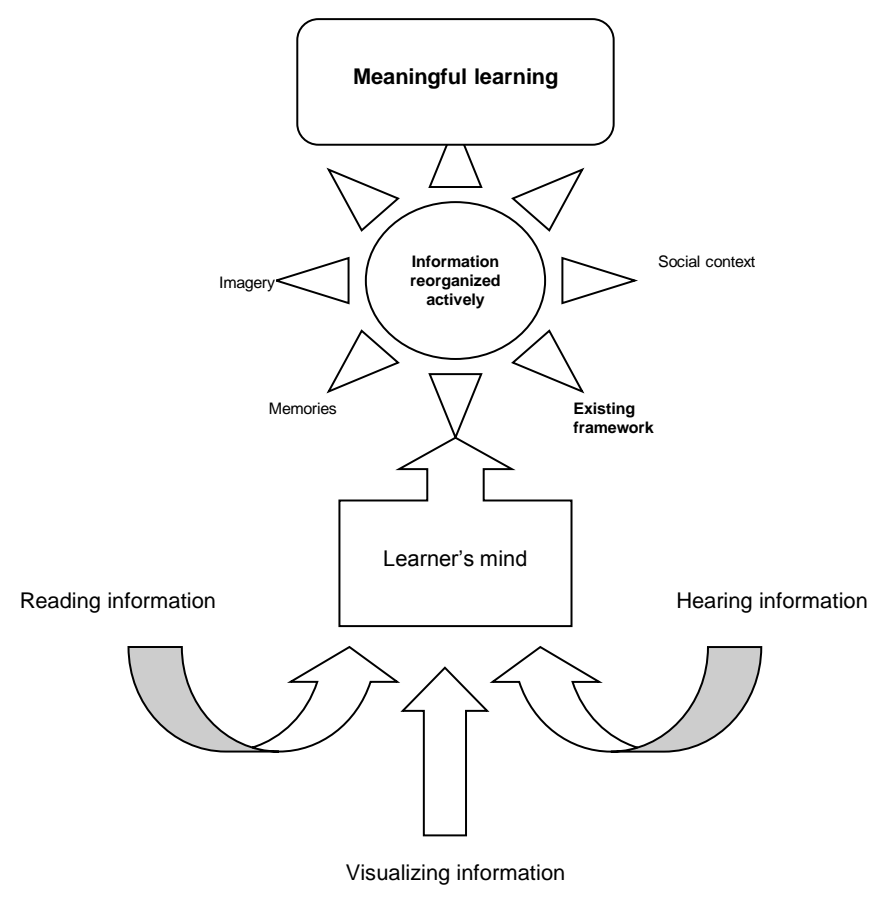

Figure 1. Theoretical assumptions that underlie constructivist theory using a bottom-up approach. Adapted from Ausubel (1978).

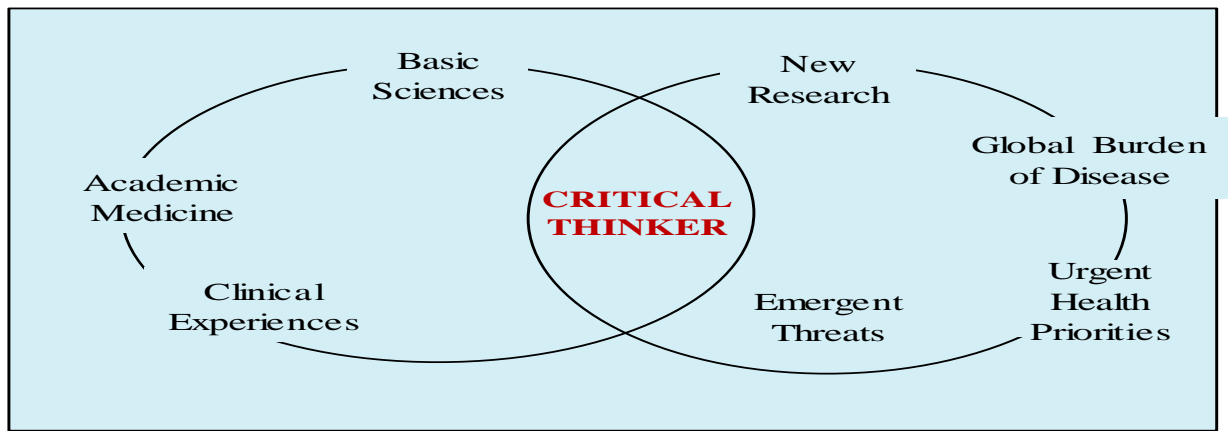

Figure 2 The Integration leading to critical thinking

Class Supported Clinical Visitation (CSCV) as we have termed it is one strategy, which we believe, promotes the integration of knowledge for the promotion of critical thinking skills in students. CSCV defines a learning strategy where the entire class along with the course instructors observe treatment sessions unfolding in a natural environment. Faculties who utilize clinical visitations believe that these observations provide students a unique opportunity to experience real patient/ therapist interactions during an actual treatment session. We believe it is that through these observations active learning is emerging and thus critical thinking is developing. 
So why are few programs using CSCV? The primary issues with CSCV offered by faculty is that arranging these clinical visitation are time consuming for the faculty member and labor intensive for the clinical site who agree to host the class visitation. Additionally, currently there is no data is available to support its effectiveness. Given the status of today's health care and the need for accountability it is important to provide evidence of the impact these clinical visitations may have on student's critical thinking skills, self confidence and overall professional readiness.

\section{PURPOSE}

To provide data on student perceptions of the usefulness of the course based clinical visitations in promoting their ability to organize, prioritize, and integrate content knowledge for the development of effective critical thinking skills.

\section{METHODS}

\section{Subjects}

Doctor of Physical Therapy (DPT) students enrolled in a neurorehabilitation course participated in three class supported clinical visitations (CSCV) as part of their class experience $(\mathrm{n}=27)$

\section{Procedures}

All Doctor of Physical Therapy (DPT) students enrolled in a neurorehabilitation course received an email with a link to a web-based survey. The research was conducted solely on that student's computer at whatever location they preferred. The survey host (ASSET, SHU) stored the survey answers until they were downloaded by the researchers into an excel file. The Survey included 17 questions: Forced response (n 11) using a 1-5 Likert scale, Open-ended (n 3), and Demographic questions (n 3). While this survey has not been validated, it was created specifically to gather information on student perceptions specific to this topic, CSCV.

The CSCV were arranged to compliment three key parts of the didactic coursework: 1. Day rehabilitation center: general, 2. In-patient rehabilitation: CVA, TBI and 3. In-patient rehabilitation: SCI.

At the end of the semester, the students were asked to complete the on-line post-course survey assessing their perception of the usefulness of the CSCV technique in promoting their ability to organize, prioritize, and integrate content knowledge for the development of effective critical thinking skills.

\section{Study design}

A quantitative, exploratory, prospective survey design was used to address the research question. The dependent variables were the survey responses regarding perceptions and the independent variable was utilization of the CSCV. Survey data analysis included the generation of percent agreement scores.

\section{RESULTS}

Although the subject pool was limited to 27 students, students perceived that the CSCV learning technique enabled them to better organize, prioritize and integrate the material presented in the course.

Table 1,2, and 3 provides the respondent's response in percentage across the liker scale from strongly agree to strongly disagree. 
Table 1. Student's Perception of Class Supported Visitations in the Areas of Prioritizing and Integrating Information (Percent Agreement)

\begin{tabular}{|c|c|c|c|c|c|}
\hline & $\begin{array}{l}\text { Strongly } \\
\text { Agree }\end{array}$ & Agree & Unsure & Disagree & $\begin{array}{l}\text { Strongly } \\
\text { Disagree }\end{array}$ \\
\hline Increased my confidence in prioritizing information & $40.0 \%$ & $51.9 \%$ & $3.7 \%$ & $3.7 \%$ & $0.0 \%$ \\
\hline $\begin{array}{l}\text { Helped me to develop my ability to prioritize patient's } \\
\text { impairments to develop a plan of care }\end{array}$ & $44.4 \%$ & $48.1 \%$ & $7.4 \%$ & $0.0 \%$ & $0.0 \%$ \\
\hline $\begin{array}{l}\text { Helped me to integrate concepts associated with various } \\
\text { neurological conditions as it relates to PT intervention }\end{array}$ & $51.9 \%$ & $44.4 \%$ & $3.7 \%$ & $0.0 \%$ & $0.0 \%$ \\
\hline
\end{tabular}

Table 2. Student's Perception of Class Supported Visitations in the Area of Developing Critical Thinking Skill (Percent Agreement)

\begin{tabular}{|c|c|c|c|c|c|}
\hline 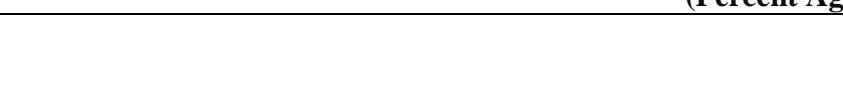 & $\begin{array}{l}\text { Strongly } \\
\text { Agree }\end{array}$ & Agree & Unsure & Disagree & $\begin{array}{l}\text { Strongly } \\
\text { Disagree }\end{array}$ \\
\hline $\begin{array}{l}\text { Enhanced my ability to think of alternate ways to explain } \\
\text { neurological concepts to my classmates }\end{array}$ & $40.7 \%$ & $55.6 \%$ & $3.7 \%$ & $0.0 \%$ & $0.0 \%$ \\
\hline
\end{tabular}

Table 3. Student's Perception of Class Supported Visitations in the Areas of Self Confidence and Overall Professional Readiness (Percent Agreement)

\begin{tabular}{|l|c|c|c|c|c|}
\hline & $\begin{array}{c}\text { Strongly } \\
\text { Agree }\end{array}$ & Agree & Unsure & Disagree & $\begin{array}{c}\text { Strongly } \\
\text { Disagree }\end{array}$ \\
\hline $\begin{array}{l}\text { Helpful when working with my patient's during a one day a } \\
\text { week clinical practicum }\end{array}$ & $37.0 \%$ & $40.7 \%$ & $14.8 \%$ & $7.4 \%$ & $0.0 \%$ \\
\hline $\begin{array}{l}\text { Improved my confidence when preparing for both the } \\
\text { neurological written and practical exams }\end{array}$ & $40.7 \%$ & $48.1 \%$ & $7.4 \%$ & $3.7 \%$ & $0.0 \%$ \\
\hline
\end{tabular}

In addition to the forced response questions used in the survey several open ended questions were included in the survey to allow the respondents the opportunity to provide qualitative comments regarding several key questions.

Key Question 1: Open Ended Comments Pro: area of organizing, prioritizing \& integrating content knowledge

- $\quad$ Allowed me to observe strategies we learned and visualize for the first time real patients with these diagnoses

- $\quad$ Helped reinforce the new concepts we were learning in class

- Great way to integrate what we learn in class and the clinical setting. Often hard to see how a patient progresses from just reading a book

- Helpful in explaining some extra concepts we did not learn in class as well as reinforcing what we have learned. Site visits are crucial in integrating class information to the clinic

- $\quad$ Site visits were great ways to put all the pieces together

- $\quad$ Helped put the "puzzle together"

\section{Key Question 2: Open Ended Comments Pro: area of self confidence and professional readiness}

- Helped take some of the initial fear out of seeing neurological patients for the first time

- Helpful to see actual therapist and their thought processes; young therapist look so confident and organized in their treatments and relationship with patients

- $\quad$ Made me more comfortable with the idea of working in a neurological rehabilitation setting

- $\quad$ I would be less intimidated by the patients and rehabilitation process

- $\quad$ Created a supported environment in which we could discuss ideas and questions with our classmates and instructors

- $\quad$ Visiting the clinics has been the best learning experience for me 


\section{Open Ended Comments Cons}

- $\quad$ More time observing each patient

- $\quad$ More "hands on" time; seeing a patient and treating a patient are completely different

- $\quad$ Emphasis on instructor feedback to students rather than peer discussions

- It was difficult to relate to what I saw in the adults to my one day clinical because I am with children

\section{DISCUSSION / CONCLUSION}

The data suggest that students have positive perceptions regarding CSCV as a learning technique that may promote active learning and critical thinking. While the data obtained from this limited educational experience cannot be generalized, it does offer some insight into the usefulness of the CSCV learning technique. Based upon these findings further work can begin to explore student's perceptions of its usefulness in a larger diverse health science student population. Second, future work must assess if CSCV is truly effective in developing a student's ability to think critically. Finally, one must ask is CSCV more effective than other active learning strategies currently used to promote critical thinking.

\section{AUTHOR INFORMATION}

Dr. Pinto Zipp is Associate Professor and Chair of the Department of Graduate Programs in Health Sciences at Seton Hall University. She received her Ed.D. from Teachers College Columbia University in 1996. She currently teaches management of neuromuscular problems in the Doctor of Physical Therapy program. Her research interests focus on, a) effects of performing dual tasks on walking performance and postural sway in children and adults, and b) curriculum design issues including the use of mind mapping and video based cases in professional education for the promotion of clinical decision making skills.

Dr. Maher is an Assistant Professor for the Department of Physical Therapy, School of Health and Medical Science at Seton Hall University. She teaches course in areas of management of neuromuscular problems, geriatric problems, orthotics and prosthetics and special topics in the Doctor of Physical Therapy program. Her research interest focus are concentrated in areas of postural control and balance in children, women and older adults, obesity in children and teaching strategies to promote professional development and critical thinking in health care students

\section{REFERENCES}

1. Austin, A.E. \& Baldwin, RG. (1991). Faculty collaboration: Enhancing the quality of scholarship and teaching. ASHE-ERIC Higher Education Report No. 7.

2. Bodner, G. M. (1986). Constructivism: A theory of knowledge. Journal of Chemical Education, 63, 873878.

3. Boyer, E.L. (1990). Scholarship reconsidered: Priorities of the professoriate. San Francisco: Jossey-Bass.

4. Bridges E, Hallinger P. Implementing Problem-Based Learning. Eugene OR: Educational Resources Information Center, University of Oregon, 1995;3.

5. Brookfield, S.D. (1990). The Skillful Teacher. San Francisco, CA: Jossey-Bass Publishers.

6. Brookfield, S.D. and S. Preskill (1999). Discussion as a Way of Teaching. San Francisco, CA: Jossey-Bass Publishers.

7. Forrest, S.P., \& Peterson, T.O. (2006). It's Called Andragogy. Academy of Management \& Education, 5(1): 119-121.

8. Pinto Zipp, G., \& Olson, V. (2008). Infusing the Mentorship Model of Education for the Promotion of Critical Thinking in Doctoral Education. Journal of College Teaching \& Learning, 5(9): 9-16.

9. Taconis, R., Ferguson-Hessler, M. G. M., \& Broekkamp, H. (2001). Teaching science problem solving: An overview of experimental work. Journal of Research in Science Teaching, 38, 442-468.

10. Threlkeld, A. J., Jensen, G. M., \& Royeen, C. B. (1999). The clinical doctorate: A framework for analysis in physical therapist education. Physical Therapy, 79, 567-581.

11. Weimer, M. (2002). Learner-Centered Teaching. San Francisco, CA: Jossey-Bass Publishers.

12. Willingham, D. T. (2007). Critical thinking: Why is it so hard to teach? American Educator, 31, 8-19. 
NOTES 